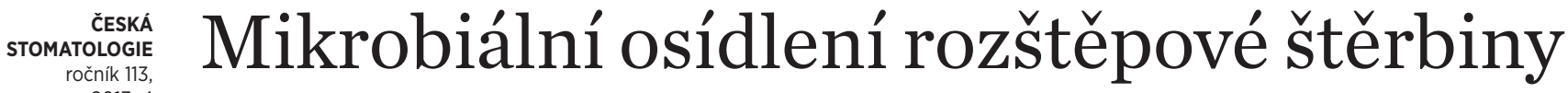

\author{
(Př́padová studie)
}

\section{Microbial Colonization of the Cleft}

\author{
(Case Study)
}

\section{Urbanová W.', Kotová M.', Leamerová E.², Dvơ̌áková J..2, Tomášková M.³}

'Stomatologická klinika 3. LF UK a FNKV, Oddělení ortodoncie a rozštěpových vad, Praha

${ }^{2}$ Klinika plastické chirurgie 3. LF UK a FNKV, Praha

${ }^{3}$ Studentka 3. LF UK, obor Dentální hygienistka, Praha

Věnováno MUDr. Magdaleně Kotóóé, Ph.D., k významnému životnímu jubileu

\section{SOUHRN}

Úvod: Základem terapie obličejových rozštěpů je chirurgická rekonstrukce měkkých a tvrdých tkání střední obličejové etáže a funkční rehabilitace pacienta. Na chirurgický léčebný protokol navazuje ortodontická, foniatrická, logopedická a stomatologická terapie, pacient je pravidelně vyšetřován na otorinolaryngologii a na jiných odděleních podle aktuální potřeby. Po operaci rozštěpu horního rtu a uzávěru patra $v$ prvním roce věku pacienta rozštěpová štěrbina $v$ místě vestibula a alveolárního výběžku perzistuje ve formě oronazální komunikace. Rekonstrukce rozštěpu alveolárního výběžku je indikována až kolem devátého roku života pacienta, její načasování určuje ortodontista podle stadia vývoje kořene stálého špičáku v místě rozštěpové štěrbiny. Členitý povrch slizničních záhybů v místě perzistujícího rozštěpového defektu je však optimálním prostředím pro množení bakterií. Přesto údaje o mikrobiálním osídlení rozštěpové štěrbiny a jeho dopad na pooperační hojení v literatuře chybí.

Cíl práce: Cílem výzkumu je zjištění mikrobiálního osídlení perzistující rozštěpové štěrbiny před chirurgickou rekonstrukcí alveolárního výběžku.

Materiál a metodika: Dvaceti pacientům, u kterých byla indikována chirurgická rekonstrukce alveolárního výběžku, byl před operací proveden výtěr z rozštěpové štěrbiny, nosu a krku.

výsledky: U dvanácti pacientů ze souboru byla alespoň v jednom z výtěrů nalezena patogenní mikroflóra. Šest vyšetřovaných jedinců mělo pozitivní stěr pouze z rozštěpové štěrbiny. Mezi nalezené bakterie $\checkmark$ rozštěpové dehiscenci patřily Staphylococcus aureus, Streptococcus pyogenes, Proteus mirabilis a Pseudomonas aeruginosa.

Závěr: Je nezbytné zvážit klinický dopad latentní infekce a výskytu potenciálních patogenů v rozštěpové štěrbině na pooperační stav a na výskyt pooperačních komplikací. Prospektivní studie zahrnující výtěry z rozštěpové štěrbiny a detailní monitorování pooperačního stavu spolu se sledováním kvantity hojící se doplněné kostní tkáně je nutná.

\section{Klíčová slova: rozštěpová štěrbina - mikrobiální osídlení - oronazální komunikace}

\section{SUMMARY}

Introduction: Surgical reconstruction of soft and hard tissues of the middle face and functional rehabilitation are keystones of the treatment of facial clefts. The surgical treatment is followed by orthodontic, phoniatric and dental treatment, also speech therapy is indicated. The patient is further regularly treated at otorhinolaryngology and at the other departments as needed. After primary surgery of the clefted upper lip and palate closure during the first year of the patient's live the cleft defect of the vestibule and alveolar process persists as oronasal fistula. The reconstruction of clefted alveolar ridge is indicated around ninth year of life, orthodontist determines the timing according to the developmental stage of 
the permanent canine on the cleft side. The rugged surface of the mucosal folds inside the cleft defect creates the optimal environment for bacterial growth. Nevertheless, data on microbial colonization of the persistent cleft gap and its impact on postoperative wound healing in the literature are lacking.

Aim: The aim of this research is to determine microbial colonization of the persistent cleft gap before surgical reconstruction of the alveolar process.

Material and Methods: In twenty patients who were scheduled for surgical reconstruction of the clefted alveolar ridge, the swabs from the cleft gap, nose and throat were taken before surgery was performed.

Results: In twelve patients from the tested group in at least one of the swabs pathogenic microorganisms were found. Six examined patients had positive result only from the cleft fissure. Among the bacteria found in the cleft dehiscence were Staphylococcus aureus, Streptococcus pyogenes, Proteus mirabilis and Pseudomonas aeruginosa.

Conclusion: It is necessary to consider the clinical impact of latent infection and the occurrence of potential pathogens in the oronasal fisstulae on the healing and on the incidence of postoperative complications. Prospective study including swabs from cleft defect and detailed postoperative monitoring along with control of the quantity of supplemented healing bone is needed.

\section{Key words: cleft - microbial population - oronasal fistula}

Čes. Stomat., roč. 113, 2013, č. 4, s. 104-111

\section{ÚVOD}

Rozštěpy rtu a čelisti patří k nejčastějším vývojovým defektům obličeje slučitelným se životem. V České republice se rodí v průměru 170 novorozenců s rozštěpovou vadou obličeje ročně. Jejich absolutní počet závisí pouze na porodnosti, poměr všech živě narozených jedinců k počtu novorozencư s rozštěpem se dlouhodobě nemění [32]. Rekonstrukce střední obličejové etáže a funkční rehabilitace postižených jedinců je výsledkem mnohaleté interdisciplinární terapie probíhající od narození až do dospělosti. Tým odborníků různých specializací pečlivě plánuje načasování jednotlivých terapeutických kroků pro dosažení optimálních výsledkư léčby [11]. Na léčbě se podílí plastický chirurg, ortodontista, otorinolaryngolog, logoped, foniatr, stomatochirurg a maxilofaciální chirurg, praktický zubní lékař, audiolog, protetik, psycholog a další specialisté podle individuálních potřeb pacienta.

Základem terapie rozštěpových defektů je chirurgická rekonstrukce měkkých a tvrdých tkání střední obličejové etáže a funkční rehabilitace pacienta. Rekonstrukční operace rozštěpové vady obličeje jsou zásadní pro vývoj řeči, u velkých rozštěpových vad umožňují lepší polykání a usnadňují dýchání. U pacienta s celkovým jednostranným rozštěpem patří k základním výkonům operace rtu, dále chirurgické uzavření patra a následně rekonstrukce alveolárního výběžku horní čelisti v místě rozštěpového defektu a řešení dentálního defektu. Rekonstrukce rtu a patra se v Centru pro léčbu vrozených vad obličeje FNKV v Praze provádějí během prvního roku života pacienta. Mezi osmým a desátým rokem je indikována chirurgická rekonstrukce zbytkové rozštěpové štěrbiny v oblasti vestibula a alveolárního výběžku spolu s doplněním kosti do oblasti defektu. Načasování tohoto výkonu určuje ortodontista podle vývojového stadia stálého špičáku v rozštěpové štěrbině. Doplnění kostní tkáně zajištuje dostatek kosti pro erupci horního špičáku, popřípadě laterálního řezáku ve stálém chrupu [5]. Optimálním výsledkem rekonstrukčních operací je kompletní uzavření rozštěpového defektu v celé jeho délce včetně skeletálního spojení a vzájemné stabilizace čelistních segmentů. K výčtu dalších chirurgických korekcí u pacientů s rozštěpem ve vyšším věku patří opakované doplnění kosti alveolárního výběžku před zavedením dentálního implantátu, uvolnění tahu slizničních řas, uzávěry oronazálních komunikací recidivujících s růstem pacienta, sekundární korekce nosu a rtu, možná je i transplantace vousů do jizevnaté tkáně horního rtu u mužư. Na chirurgický léčebný protokol navazuje léčba ortodontická, foniatrická a logopedická, pacient je pravidelně sledován a ošetřován na otorinolaryngologii a na jiných odděleních podle aktuální potřeby [18, 30, 33].

Podle terapeutického protokolu Centra pro léčbu vrozených vad obličeje FNKV v Praze a mnoha dalších pracovišt' je sice u jedince s celkovým rozštěpem v prvním roce života indikováno operativní uzavření rozštěpu horního rtu a rekonstrukce nosního vchodu a posléze i operativní uzávěr měkkého a tvrdého patra až do foramen incisivum, avšak rozštěp v místě 


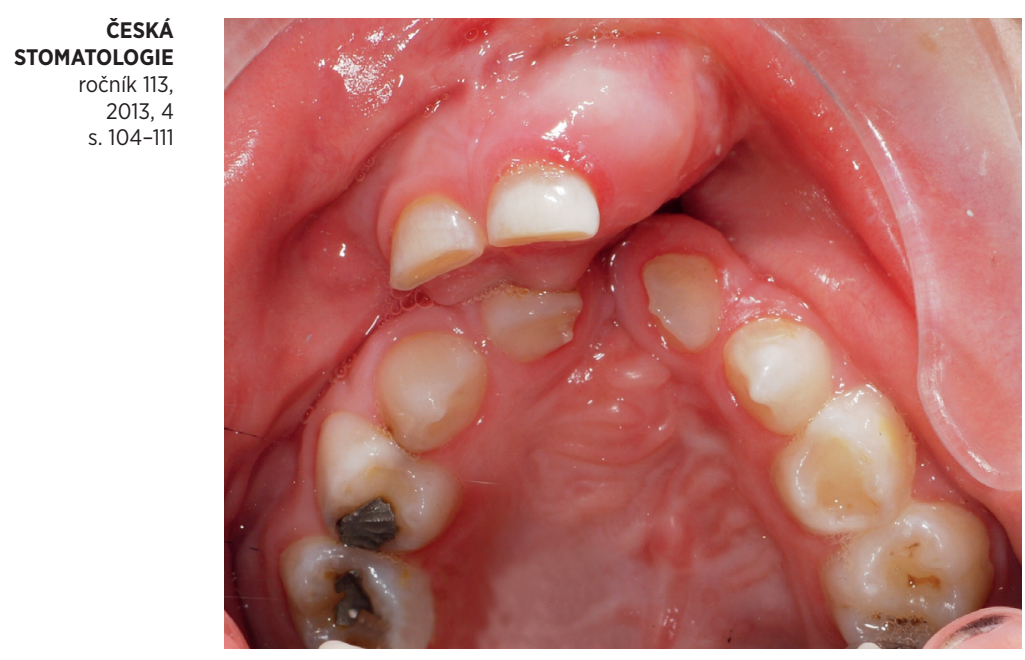

Obr. 1 Transverzálně kolabovaná horní čelist pacienta s oboustranným celkovým rozštěpem ve věku šesti let. Vlevo, v místě rozštěpu alveolárního výběžku, je široce otevřená oronazální komunikace

vestibula a alveolárního výběžku perzistuje až do doby jeho chirurgické rekonstrukce kolem devátého roku života pacienta (obr. 1). Otvor spojující ústa a dutinu nosní je pro tyto pacienty běžnou součástí života. Klinicky se komunikace může projevovat regurgitací potravy a tekutin - především šumivých nápojů, zápachem $z$ úst či nosu a poruchami rezonance řeči [1, 8, 12, 21]. Míra komplikací záleží především na velikosti defektu. U větších dehiscencí byla prokázána i transmise patogenních bakterií z nosní dutiny do úst a naopak $[6,7,31]$. Část oronazálních či vestibulonazálních komunikací nepřináší svému nositeli žádné klinické obtíže - jsou klinicky němé. Ve většině těchto případů okraje rozštěpového defektu na sebe volně naléhají a defekt je zjistitelný pouze sondáží. Ve členitém povrchu slizničních záhybů v místě rozštěpové štěrbiny, obdobně jako v kryptách patrových mandlí či na povrchu jazyka, je optimální prostředí pro množení bakterií [34]. Překvapivě málo studií však popisuje výsledky výtěrů přímo z rozštěpového defektu, u většiny dostupných výzkumů se zjištovalo bakteriální osídlení u pacientů s rozštěpem dutiny nosní, orofaryngu či vestibula $[4,9]$. Pokud byly v rámci studie výtěry zhotoveny přímo z rozštěpové štěrbiny, šlo o zjištění bakteriálního osídlení dehiscence ještě před primární rekonstrukcí rtu nebo patra, či o výzkum mikrobiální flóry v dlouhodobě perzistující oronazální komunikaci u dospělého pacienta $[4,20]$. Proto je cílem našeho výzkumu zjištění potenciálně patogenní mikroflóry v perzistující rozštěpové štěrbině před chirurgickou rekonstrukcí a doplněním kosti alveolárního výběžku ve stadiu smíšené dentice.

\section{MATERIÁL A METODIKA}

Do výzkumu bylo zahrnuto dvacet pacientů s rozštěpem rtu a alveolárního výběžku (čtyři pacienti) a jednostranným (třináct pacientů) či oboustranným celkovým rozšsěpem (tř̌i pacienti). Průměrný věk pacientů při vyšetření byl 9 let a 10 měsíců $\pm 1,3$ roku. Velikost ani šiřka rozštěpové dehiscence nebyla monitorována. U všech pacientů byla indikována chirurgická rekonstrukce alveolárního výběžku a doplnění kosti do rozštěpové štěrbiny. Během výkonu a pooperačně byla pacientům podávána antibiotika (tab. 1).

Před přijetím pacienta na lưžkové oddělení Kliniky plastické chirurgie 3. LF UK a FNKV Praha byly, kromě rutinních výtěrů $z$ dutiny nosní a orofaryngu, zhotoveny i stěry $z$ rozštěpového defektu $v$ celé jeho šířce a hloubce. Sterilní tampon byl při stěru lehkým tlakem zaveden do rozštěpové štěrbiny tak, aby se provedl odběr $z$ co největší plochy sliznice mezi rozštěpovými segmenty maxily. Tampon byl vložen do transportní soupravy s vyloučením kontaminace z jiných povrchů. Vzorky byly, spolu s výtěry z dutiny nosní a orofaryngu, odeslány do Ústavu laboratorní diagnostiky FNKV, kde se provedla standardní kultivace a diagnostika nálezů.

Př̀i nálezu běžné flóry či komenzálních bakterií úst a dýchacích cest (tj. Candida albicans, Streptococcus viridans v rozštěpové štěrbině a Streptococcus pneumoniae v dutině nosní či orofaryngu) byl výsledek výtěru považován za negativní $[15,17,26]$. Pokud byly zjišsěny Staphylococcus aureus, Moraxella catarrhalis, ß-hemolytické streptokoky a další bakterie, které nepatří mezi komenzální osídlení dutiny ústní, nosu a orofaryngu, byl nález hodnocen jako pozitivní.

\section{VÝSLEDKY}

Výsledky výtěrů u jednotlivých pacientů s rozštěpem jsou přehledně zobrazeny $\mathrm{v}$ tabulce 1 .

\section{Výsledky výtěrů z rozštěpové štěrbiny, nosu a krku}

Z dvaceti vyšetřených pacientů s rozštěpem byl $u$ dvanácti alespoň jeden $z$ výtěrů pozitivní, tj. nalezla se patogenní flóra $v$ jednom, dvou či všech třech stěrech. U osmi pacientů byla v rozšsěpové štěrbině, nosu a krku nalezena běžná flóra. Výskyt patogenů nebyl závislý na typu rozštěpu či pohlaví pacienta.

U šesti jedinců ze souboru se nalezla potenciálně patogenní bakteriální flóra pouze v rozštěpu, zatímco výsledky výtěrů z nosu a krku byly negativní, jen 


\begin{tabular}{|c|c|c|c|c|c|c|c|}
\hline & a v poope & račním ob & odobí & 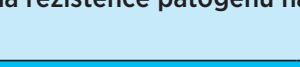 & 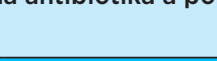 & & 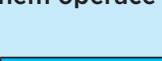 \\
\hline & & & & /ýsledky výtěrů & & Zjištěná rezisten- & \\
\hline Pactem & Dlagnoza & Pomiavi & ROZŠTĚPOVÁ ŠTĚRBINA & NOS & KRK & ce na ATB & 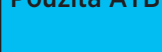 \\
\hline A & BCLP & q & Staphylococcus aureus & Staphylococcus aureus & běžná flóra & Amoxicilin & Amoksiklav \\
\hline B & UCLP & $\hat{0}$ & $\begin{array}{l}\text { Candida albicans } \\
\text { Klebsiella oxytoca } \\
\text { viridujíci Streptococcus }\end{array}$ & $\begin{array}{l}\text { Streptococcus pneu- } \\
\text { moniae }\end{array}$ & $\begin{array}{l}\text { Streptococcus } \\
\text { pneumoniae }\end{array}$ & Amoxicilin & Amoksiklav \\
\hline C & UCLP & q & $\begin{array}{l}\text { Staphylococcus koaguláza } \\
\text { negativní }\end{array}$ & Staphylococcus aureus & $\begin{array}{l}\text { Staphylococcus } \\
\text { aureus }\end{array}$ & $N E$ & Klacid \\
\hline D & UCLP & $\hat{\sigma}$ & $\begin{array}{l}\text { Streptococcus pneumo- } \\
\text { niae }\end{array}$ & $\begin{array}{l}\text { Streptococcus pneu- } \\
\text { moniae }\end{array}$ & běžná flóra & $N E$ & Augmentin \\
\hline$E$ & $R+A$ & 우 & Proteus mirabilis & běžná flóra & běžná flóra & $\begin{array}{l}\text { Amoxicilin } \\
\text { Amoxicilin/ } \\
\text { klavulanát } \\
\text { Cefuroxim } \\
\end{array}$ & Amoksiklav \\
\hline $\mathrm{F}$ & $R+A$ & 우 & Streptococcus sp. & běžná flóra & běžná flóra & NE & Amoksiklav \\
\hline G & UCLP & $\hat{\sigma}$ & Pseudomonas aeruginosa & $\begin{array}{l}\text { Streptococcus pneu- } \\
\text { moniae }\end{array}$ & běžná flóra & NE & Augmentin \\
\hline H & UCLP & $\hat{\sigma}$ & Candida albicans & běžná flóra & běžná flóra & NE & Dalacin \\
\hline $\mathrm{CH}$ & UCLP & o & $\begin{array}{l}\text { Klebsiella pneumoniae } \\
\text { Staphylococcus aureus }\end{array}$ & \begin{tabular}{l|} 
Streptococcus \\
pneumoniae, \\
Staphylococcus aureus
\end{tabular} & běžná flóra & NE & Augmentin \\
\hline 1 & BCLP & $\sigma^{2}$ & $\begin{array}{l}\text { Streptococcus } \\
\text { pneumoniea } \\
\text { Klebsiella oxytoca } \\
\text { Staphylococcus aureus }\end{array}$ & $\begin{array}{l}\text { Streptococcus } \\
\text { pneumoniae }\end{array}$ & $\begin{array}{l}\text { Klebsiella } \\
\text { oxytoca }\end{array}$ & NE & Amoksiklav \\
\hline J & UCLP & $\sigma^{2}$ & běžná flóra & běžná flóra & $\begin{array}{l}\text { Staphylococcus } \\
\text { aureus }\end{array}$ & NE & Amoksiklav \\
\hline K & BCLP & $\hat{0}$ & $\begin{array}{l}\text { Klebsiella pneumoniae } \\
\text { Streptococcus } \\
\text { beta-haemolyticus C }\end{array}$ & běžná flóra & běžná flóra & $\begin{array}{l}\text { Amoxicilin; } \\
\text { Clotrimazol } \\
\text { Amoxicilin/ } \\
\text { klavulanát }\end{array}$ & Xorimax \\
\hline $\mathrm{L}$ & UCLP & o & Staphylococcus aureus & Staphylococcus aureus & běžná flóra & NE & Zinacef \\
\hline M & $R+A$ & q & běžná flóra & běžná flóra & běžná flóra & NE & Dalacin \\
\hline N & UCLP & o & běžná flóra & běžná flóra & běžná flóra & NE & Augmentin \\
\hline O & UCLP & q & Candida albicans & $\begin{array}{l}\text { Moraxella catarrhalis } \\
\text { Staphylococcus aureus }\end{array}$ & běžná flóra & NE & Dalacin \\
\hline$P$ & UCLP & $\hat{0}$ & běžná flóra & běžná flóra & běžná flóra & NE & Amoksiklav \\
\hline Q & UCLP & q & \begin{tabular}{l|} 
viridující Streptococcus \\
Staphylococcus koaguláza \\
negativní
\end{tabular} & $\begin{array}{l}\text { Streptococcus } \\
\text { pneumoniae }\end{array}$ & běžná flóra & NE & Dalacin \\
\hline $\mathrm{R}$ & $R+A$ & o & $\begin{array}{l}\text { Streptococcus pyogenes } \\
\text { skupina } A\end{array}$ & Staphylococcus aureus & \begin{tabular}{|l|}
$\begin{array}{l}\text { Streptococcus } \\
\text { pyogenes } \\
\text { skupina A }\end{array}$ \\
\end{tabular} & NE & Unasyn \\
\hline S & UCLP & 3 & běžná flóra & běžná flóra & běžná flóra & NE & Amoksiklav \\
\hline
\end{tabular}

Tučně - nalezené patogenní bakterie, šedě - komenzální bakterie. UCLP - jednostranný celkový rozštěp, BCLP - oboustranný celkový rozštěp, R+A - rozštěp rtu a alveolárního výběžku, $\delta$ - chlapec, $\uparrow$ - dívka, ATB - antibiotika. 
u dvou pacientů byly patogenní bakterie zjištěny pouze mimo rozštěpovou dehiscenci, tedy na nosní a orofaryngeální sliznici.

$\mathrm{U}$ jednoho pacienta byla ve stěrech $\mathrm{z}$ nosu diagnostikována Moraxella catarrhalis.

\section{Výsledky výtěrů z rozštěpové štěrbiny}

U devíti pacientů se ve výtěrech $\mathrm{z}$ rozštěpové dehiscence nalezly bakterie, které mohou zpưsobit závažnou infekci, u dalších tří jedinců z vyšetřovaného souboru byly nalezeny potencionálně patogenní druhy rodů Staphylococcus a Streptococcus bez další specifikace. Čtyři pacienti měli rozštěpovou štěrbinu osídlenou bakteriemi Staphylococcus aureus, jeden Streptococcus pyogenes, $\mathrm{u}$ dalších dvou byly z rozštěpu vykultivovány Proteus mirabilis a Pseudomonas aeruginosa. U tří pacientů byla vedle viridujících streptokoků diagnostikována i Candida albicans.

\section{DISKUSE}

Výtěry patří mezi rutinní diagnostická předoperační vyšetření u pacientů s rozštěpem [27]. Standardně se v předoperačním období zhotovují mikrobiální stěry z dutiny nosní a orofaryngu, i když klinický přínos těchto vyšetření je v poslední době odbornou veřejností zpochybňován [19, 25, 29]. Thomas a kol. [29] zhotovili stěry z nosu a krku dva týdny před operací rtu a patra a další sérii výtěrů těsně před začátkem operace. Výsledky před- a peroperačních výtěrů se shodovaly pouze v polovině případů. Proto autoři konstatovali, že zhotovení stěrů z dutiny nosní a orofaryngu dva týdny před primární rekonstrukcí rozštěpové vady není z hlediska zjištění rizika pooperační infekce rány relevantní. Dále poukázali na to, že výtěr z dutiny nosní byl pozitivní u větší části pacientů s rozštěpem než výtěr $z$ orofaryngu. Proto před primární rekonstrukcí rozštěpové vady pro zjištění rizikové bakteriální flóry Thomas a kol. [29] doporučují spíše zhotovení výtěrů z nosních dírek v co nejkratší době před operací. Žádná studie v dostupné literatuře se však nezabývá bakteriálním osídlením relativně úzké a částečně uzavřené perzistující rozštěpové štěrbiny u pacientů ve smíšeném chrupu před doplněním kosti do defektu alveolárního výběžku. Vzhledem k lokalizaci plánované chirurgické rekonstrukce a zde prezentovaným výsledkưm, kdy část pacientů měla pozitivní výsledek výtěru pouze $z$ rozštěpové štěrbiny a negativní stěr z nosu a krku, může mít nález patogenní mikroflóry v defektu krátce před operací významnější přínos pro pooperační průběh a hojení a pro dlouhodobou stabilitu výsledku alveolární rekonstrukce než vzorky mikrobiální flóry z orofaryngu či nosní sliznice.

Komplikace chirurgických rekonstrukcí rozštěpové štěrbiny zahrnují částečnou dehiscenci rány a vznik oronazální či vestibulonazální komunikace, otok a pyrexii z důvodu bakteriální infekce, krvácení nebo velké jizvení. Komplikace jsou přičítány především zánětu [2], ale i excesivní tenzi měkkých tkání po operaci rozsáhlého rozštěpu [22], technice chirurgického zákroku a zkušenostem chirurga [1, 13]. Mezi méně diskutované komplikace patří zánětlivá resorpce části či kompletní ztráta doplněné kosti při chirurgické rekonstrukci alveolárního výběžku. Výzkumy, které by objasnily souvislost infekce, dehiscenci rány a míru resorpce doplněné kostní hmoty, však chybí. Většina studií zabývajících se touto problematikou je soustředěna na zjištění příčin a frekvenci výskytu oronazálních komunikací po primární rekonstrukci rtu a patra. Patogeny nejčastěji dávané do souvislosti se vznikem oronazálních defektů po operaci patra jsou Staphylococcus aureus a ß-hemolytické streptokoky [14,15].

Rennie a kol. [25] uvádějí, že došlo k vytvoření oronazální komunikace u kojenců po primární rekonstrukci rozštěpu patra, u kterých se v pooperačním období vyskytla infekce horních cest dýchacích. Obdobně i Narinesingh a kol. [23] zkoumali vliv mikrobiální flóry nosu a krku na vznik píštělí po operaci patra. Dehiscence rány a opětovná oronazální komunikace se procentuálně nejvíce vyskytla u pacientů s latentní infekcí Moraxella catarrhalis (50\%); další nejčastější bakterie byly z rodu streptokoků skupiny B $(28,6 \%)$ a Staphylococcus aureus $(23,1 \%)$. Výtěry $z$ rozštěpové štěrbiny však nebyly $v$ této studii provedeny. Moraxella catarrhalis byla naleze-

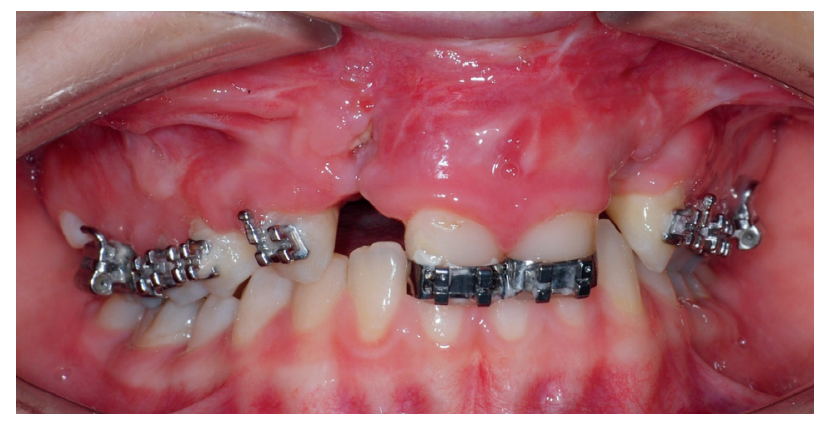

Obr. 2

Příklad možných komplikací po chirurgické rekonstrukci alveolárního výběžku u dvanáctileté pacientky s oboustranným celkovým rozštěpem - 3 měsíce po výkonu je v místě operce viditelná malá dehiscence a zánět měkkých tkání,

dochází k částečnému odhojování doplněného kostního materiálu. Fixní ortodontický aparát slouží pro stabilizaci čelistních segmentů, není prováděna aktivní ortodontická terapie. Pro účely fotodokumentace byl sejmut ortodontický oblouk 
na i ve stěru $z$ dutiny nosní u jednoho pacienta ze zde vyšetřovaného souboru. Přestože může být v malých množstvích přítomna v dutině ústní i za fyziologických podmínek, na Moraxellu catarrhalis se v současné době upíná pozornost jako na významný oportunní lidský patogen. Byla identifikována jako častá příčina bronchopulmonální infekce, zvláště u pacientů s poruchou imunitního systému. Mưže vyvolat zánět středního ucha, bronchitidu, akutní sinusitidu, meningitidu, zánět spojivek či uretritidu. U žádného pacienta $z$ našeho souboru nedošlo k vytvoření opětovné oronazální komunikace, byly však pozorovány pooperační komplikace typu zánětu měkkých tkání a částečného odhojování doplněné kostní tkáně (obr. 2).

Na současném výzkumu nás nejvíce zajímaly výsledky výtěrů z perzistující rozštěpové štěrbiny, protože údaje o mikrobiálním osídlení této oblasti v literatuře chybějí. U části jedinců z našeho souboru byly vykultivovány mikroorganismy pro dutinu ústní, nos či larynx netypické. Šlo o latentní infekci či nosičství této bakterie, bez klinických příznaků onemocnění. Čtyřri pacienti $z$ vyšetřované skupiny měli rozštěpovou štěrbinu osídlenou druhem Staphylococcus aureus - grampozitivní bakterií, která je v populaci často příčinou různých infekcí v rozsahu od mírných zánětů kůže a měkkých tkání až po život ohrožující sepse, syndrom toxického šoku či nekrotizující pneumonie. Ve všech čtyřech případech byla u Staphylococcus aureus zjištěna dobrá citlivost na antibiotika, přítomnost meticilin-rezistentních kmenů se neprokázala. Výskyt zlatého stafylokoka ve výtěru z nosní sliznice či orofaryngu je spolu se zjištěním osídlení hemolytickým streptokokem v literatuře dáván do souvislosti s rizikem vzniku oronazální komunikace a dehiscence rány po operaci rtu a patra $[14,15,16,23]$. Beta-hemolytický streptokok byl kultivován $z$ výtěru rozštěpové štěrbiny dvou pacientů ze souboru.

Neobvyklé je bakteriální osídlení rozštěpové štěrbiny u pacientů E a G. Proteus mirabilis u pacienta E je gramnegativní, fakultativně anaerobní bakterie, která je u člověka odpovědná především za tvorbu renálních kamenů a urologické infekce. Zjištění této bakterie v dutině ústní není standardní. Při rozšíření infekce může tato bakterie způsobit infekci rány, septikémii či pneumonii, především u dlouhodobě hospitalizovaných pacientù. U Proteus mirabilis ve výtěru pacienta $\mathrm{E}$ byla zjištěna rezistence $\mathrm{k}$ antibiotikưm penicilinové řady, Nitrofurantoinu a Cefuroximu. Vliv podávání Amoksiklavu peroperačně a v pooperačním období na výskyt a pomnožení této bakterie je nejistý. U pacienta G byla v rozštěpové štěrbině zjištěna gramnegativní bakterie Pseudomonas aeruginosa, patřící do skupiny pseudomonád, která je schopná přežít i v prostředí s nedostatkem kyslíku. Tato bakterie se za běžných okolností v dutině ústní nevyskytuje, přesto byla $v$ jiných studiích u pacientů s rozštěpem vykultivována po primární rekonstrukci patra ze stěrư $z$ patrové sliznice $\mathrm{v}$ pooperačním období [22]. Protože ulpívá a přežívá na většině povrchů, například na zdravotnickém vybavení, při nedodržení hygienických norem ve zdravotnickém zařízení je možný přenos této bakterie mezi pacienty. Jde o potenciální patogen - při snížení imunity napadá Pseudomonas aeruginosa orgány a může způsobit sepsi, nalézá se také v chronických kožních ranách. Rezistence na antibiotika u bakteriální flóry v rozštěpové štěrbině, krku a nosu pacienta $\mathrm{G}$ nebyla nalezena, podle zjištěné citlivosti mezi doporučené léky patřil Gentamycin, Piperacilin/Tayobactam, Colistin a Ciprofloxacin. Vliv podávaného Augmentinu na výskyt a pomnožení této konkrétní bakterie je opět diskutabilní.

Kvasinka Candida albicans se za fyziologických podmínek v ústech vyskytuje až u 80 \% populace. U pacientů s rozštěpem ve věku deset let po opakovaných operacích byla dokonce prokázána větší kolonizace dutiny ústní touto kvasinkou než u jejich zdravých vrstevníků [24]. V prezentovaném souboru byla nalezena $\mathrm{v}$ rozštěpovém defektu tří vyšetřovaných. Otázkou je, zda její výskyt v rozštěpové štěrbině také můžeme považovat za „běžný“. Ve studii Mÿburgh a Bütow [22] došlo během několika dnư po operaci patra $\mathrm{k}$ nárůstu počtu pacientů, u kterých byla ve stěrech z patrové sliznice diagnostikována Candida albicans. Tato kvasinka nikdy nebyla dávána do souvislosti s pooperačními komplikacemi, zřejmě proto, že se stává patogenní hlavně při snížení imunity organismu. Candida albicans však byla prokázána v chronických ranách, její negativní vliv na pooperační hojení tkáně proto nelze vyloučit $[10,28]$.

Na rozdíl od jiných výzkumů, kde byly zhotoveny výtěry z nosní dutiny a orofaryngu u kojenců, nebyly ve stěrech $z$ rozštěpové štěrbiny $u$ zde prezentované skupiny skoro desetiletých pacientů nalezeny koliformní bakterie, např́iklad Escherichia coli či rod Enterobacter [16, 22].

Doporučení, jak se zachovat při výskytu patogenů či potenciálně patogenních bakterií v rozštěpové dehiscenci, v literatuře chybí, protože výtěry z lokality rozštěpu nejsou běžně zhotovované. $\mathrm{Z}$ tabulky s výsledky je zřejmé, že pacientům $\mathrm{A}, \mathrm{B}$ a E v našem souboru byla podávána antibiotika penicilinové řady, na která byla u bakterií nalezených v rozštěpové štěrbině prokázána rezistence. Stalo se tak proto, že $\mathrm{v}$ době operace byly $\mathrm{k}$ dispozici pouze předběžné výsledky výtěrů, zatímco definitivní bakteriologický 
nález, včetně zjištění rezistence, byl znám až druhý den po operaci. Terapeutický tým Centra pro léčbu vrozených obličejových vad FNKV na základě těchto nových poznatkư rozhodl o změně v načasování výtěrů a u dalších pacientů byly stěry $z$ rozštěpové štěrbiny, nosu a faryngu zhotoveny v dostatečném předstihu před chirurgickým zákrokem.

Také při zjištění pozitivního nálezu výtěrů nosu a orofaryngu se terapeutické protokoly jednotlivých center specializujících se na léčbu rozštěpových vad rozcházejí. V některých pacient podstoupí kúru antibiotiky určenými podle citlivosti bakterií a operace následuje bez kontrolního výtěru [29], v jiných se během operace podává nárazová dávka specifických antibiotik [27] či je operace odložena o několik týdnů až měsíců do doby, kdy jsou výsledky výtěrů negativní (např. Centrum pro léčbu vrozených obličejových vad FNKV Praha). Existují i léčebné protokoly, kde předoperační stěry nejsou zhotovovány, pokud pacient nevykazuje žádné klinické známky infekce (např. Cleft Palate Craniofacial Unit Nijmegen, Nizozemsko). Mezi jednotlivými centry se také liší strategie antibiotické profylaxe během a po operaci u pacientů s negativním výtěrem, a to jak načasováním, délkou podávání, tak i používanými léky. Smyth a Knepil [27] dotazníkovou studií v rozštěpových centrech na území Velké Británie prokázali, že neexistuje jednotný konsenzus v indikaci a délce antibiotické profylaxe při rekonstrukcích rtu a patra u pacientů s rozštěpovým defektem. Většinou se podá nárazová dávka antibiotik během operace, často se tyto léky podávají i v pooperačním období. Mezi používaná antibiotika patří například Augmentin, Amoksiklav či Dalacin (Centrum pro léčbu vrozených obličejových vad FNKV Praha) [29], Azithromycin [3], nebo kombinace Kefzolu s chemoterapeutikem Metronidazolem (CPCU Nijmegen) a další. Souhrnný počet operací u pacienta s celkovým rozštěpem během celého jeho života je v prưměru čtyři; v individuálních případech i víc - jde o primární či sekundární rekonstrukční operace, aplikace ventilačních trubiček do bubínků atd. Proto existuje reálné riziko vzniku rezistentních bakteriálních kmenů v mikrobiální flóře dutiny ústní a nosní. Studie autorů Mÿburgh a Bütow [22] se zabývala mikrobiálním osídlením dutiny ústní a vznikem rezistence na antibiotika u sta pacientů s rozštěpem. Všem byly odebrány čtyři po sobě následující kontrolní výtěry z oblasti sliznice patra a orofaryngu těsně před, dva dny, čtyři dny a šest dnů po chirurgické rekonstrukci patra. Antibiotika byla použita profylakticky během i po operaci rozštěpového defektu (autoři ve studii přesný název léku nezmiňují). Kultivace prokázala významný postupný nárůst počtu vzorků s Candida albicans, Pseudomonas aeruginosa a pokles Staphylococcus aureus v pooperačním období. Dále studie poukazuje na vznik rezistence mikroorganismů vůči některým antibiotikům, konkrétně vůči Ampicilinu, první a druhé generaci cefalosporinů a Ampicilin-klavulanátu. Závěrem studie je poukázáno na fakt, že použití profylaktické antibiotické léčby po operaci by mělo být omezeno na minimum a léčba by měla být cílená, s ohledem na možnost vytvoření rezistence bakterií [22]. I výsledky stávajícího výzkumu, respektive zjištění rezistentních bakteriálních kmenů $\mathrm{v}$ rozštěpové štěrbině, poukazují na nutnost cílené antibiotické terapie během a po chirurgické rekonstrukci alveolárního výběžku.

\section{ZÁVĚR}

Výsledky výtěrů z rozštěpové štěrbiny byly pozitivní u více než poloviny vyšetřovaných pacientů s rozštěpem, byly diagnostikovány i potenciálně patogenní mikroorganismy pro oblast dutiny ústní netypické.

Výsledky výtěrů je třeba posuzovat kriticky a zvážit klinický dopad latentní infekce a výskyt potenciálních patogenů v dutině nosní, orofaryngu a v rozštěpové štěrbině na pooperační stav a na výskyt komplikací u operovaných pacientů. Prokázaný výskyt patogenního osídlení rozštěpové štěrbiny před chirurgickou rekonstrukcí alveolárního výběžku a doplněním kosti však není radno brát na lehkou váhu, vzhledem $\mathrm{k}$ lokalizaci operace a velké tendenci vhojující se kosti k resorpci. Na základě zjištění patogenního osídlení rozštěpové dehiscence byl v Centru pro léčbu vrozených vad obličeje FNKV modifikován terapeutický protokol. Výtěry z rozštěpu, nosu a krku jsou zhotoveny pět dnư až týden před plánovanou operací a při jejich pozitivním výsledku je v době přijetí pacienta na lůžkové oddělení nasazena antibiotická léčba podle zjištěné citlivosti, která pokračuje i v pooperačním období.

Je nutné provést prospektivní studii na větším souboru pacientů zahrnující výtěry z rozštěpové štěrbiny a detailní monitorování pooperačních komplikací spolu se sledováním kvality a kvantity hojící se doplněné kostní tkáně.

\section{LITERATURA}

1. Abyholm, F. E., Borchgrevink, H. H., Eskeland, G.: Palatal fistulae following cleft palate surgery. Scand. J. Plast. Reconstr. Surg., roč. 13, 1979, č. 2, s. 295-300.

2. Almasri, M.: Reconstruction of the alveolar cleft: effect of preoperative extraction of deciduous teeth at the sites of clefts on the incidence of postoperative complications. Br. J. Oral. Maxillofac. Surg., roč. 50, 2012, č. 2, s. 154-156. 
3. Amland, P. F., Andenaes, K., Samdal, F., Lingaas, E., Sandsmark, M., Abyholm, F., Giercksky, K. E.: A prospective, double-blind, placebo-controlled trial of a single dose of azithromycin on postoperative wound infections in plastic surgery. Plast. Reconstr. Surg., roč. 96, 1995, č. 6, s. 1378-1383.

4. Arief, E. M., Mohamed, Z., Idris, F. M.: Study of viridans streptococci and staphylococcus species in cleft lip and palate patients before and after surgery. Cleft Palate Craniofac. J., roč. 42, 2005, č. 3, s. 277-279.

5. Arosarena, O. A.: Cleft lip and palate. Otolaryngol. Clin. North Am., roč. 40, 2007, č. 1, s. 27-60.

6. Brennan, P. A., Markus, A. F., Flood, T. R., Downie, I. P., Uppal, R.: Do oral flora colonize the nasal floor of patients with oronasal fistulae? Cleft Palate Craniofac. J., roč. 38, 2001, č. 4 s. 399-400.

7. Brennan, P. A., Willy, P., Anand, R., Markus, A. F.: Colonization of the cleft nasal floor by anaerobic oral flora in patients with oronasal fistulae. Cleft Palate Craniofac. J., roč. 40, 2003, č. 4, s. 431-432.

8. Bureau, S., Penko, M., McFadden, L.: Speech outcome after closure of oronasal fistulas with bone grafts. J. Oral. Maxillofac Surg., roč. 59, 2001, č. 12, s. 1408-1414.

9. Cocco, J. F., Antonetti, J. W., Burns, J. L., Heggers, J. P. Blackwell, S. J.: Characterization of the nasal, sublingual, and oropharyngeal mucosa microbiota in cleft lip and palate individuals before and after surgical repair. Cleft Palate Craniofac. J., roč. 47, 2010, č. 2, s. 151-155.

10. Dowd, S. E., Delton Hanson, J., Rees, E., Wolcott, R. D., Zischau, A. M., et al: Survey of fungi and yeast in polymicrobial infections in chronic wounds. J. Wound Care, roč. 20, 2011, č. 1, s. $40-47$.

11. Dušková, M. Pokroky v sekundární léčbě nemocných s rozštěpem. 1. vyd. Hradec Králové: Olga Čermáková, 2007.

12. Eufinger, H., Machtens, E. Microsurgical tissue transfer for rehabilitation of the patient with cleft lip and palate. Cleft Palate Craniofac. J., roč. 39, 2002, č. 5, s. 560-567.

13. Emory, R. E. Jr., Clay, R. P., Bite, U., Jackson, I. T.: Fistula formation and repair after palatal closure: an institutional perspective. Plast. Reconstr. Surg., roč. 99, 1997, č. 6, s. 1535-1538.

14. Hupkens, P., Lauret, G., Dubelaar, I., Hartman, E., Spauwen, P.: Prevention of wound dehiscence in palatal surgery by preoperative identification of group A Streptococcus and Staphylococcus aureus. Eur. J. Plast. Surg., 2007, č. 29, s. 321-325.

15. Chuo, C. B., Timmons, M. J.: The bacteriology of children before primary cleft lip and palate surgery. Cleft Palate Craniofac. J. roč. 42, 2005, č. 3, s. 272-276.

16. Jolleys, A., Savage, J.: Healing defects in cleft palate surgery the role of infection. Brit. J. Plast. Surg., 1963, č. 16, s. 134-139.

17. Marsh, P., Martin, M.: Oral microbiology. $3^{\text {rd }}$ ed. London, Chapman \& Hall, 1992.

18. Meazzini, M. C., Bozzetti, A., Brusati, R., Mazzoleni, F., Garattini, G., Felisati, G., Lalatta, F., Rezzinico, A.: Craniofacial anomalies: surgical-orthodontic management. Bologna, Edizioni Martina, 2011.

19. Mercer, N. S.: The use of preoperative swabs in cleft lip and palate repair. Br. J. Plast. Surg., roč. 55, 2002, č. 2, s. 176-177.
20.Mombelli, A., Brägger, U., Lang, N. P.: Microbiota associated with residual clefts and neighboring teeth in patients with cleft lip, alveolus, and palate. Cleft Palate Craniofac. J., roč. 29, 1992, č. 5, s. 463-469.

21. Murphy, T. C., Willmot, D. R.: Image analysis of oronasal fistulas in cleft palate patients acquired with an intraoral camera. Plast. Reconstr. Surg., roč. 115, 2005, č. 1, s. 31-37.

22. Mÿburgh, H. P., Bütow, K. W.: Cleft soft palate reconstruction: prospective study on infection and antibiotics. Int. J. Oral. Maxillofac. Surg., roč. 38, 2009, č. 9, s. 928-932.

23. Narinesingh, S. P., Whitby, D. J., Davenport, P. J.: Moraxella catarrhalis: an unrecognized pathogen of the oral cavity? Cleft Palate Craniofac. J., roč. 48, 2011, č. 4, s. 462-464

24. Rawashdeh, M. A., Ayesh, J. A., Darwazeh, A. M.: Oral candidal colonization in cleft patients as a function of age, gender, surgery, type of cleft, and oral health. J. Oral Maxillofac. Surg., roč. 69 , 2011, č. 4, s. 1207-1213.

25. Rennie, A., Treharne, L. J., Richard, B.: Throat swabs taken on the operating table prior to cleft palate repair and their relevance to outcome: a prospective study. Cleft Palate Craniofac. J., roč. 46, 2009, č. 3, s. 275-279.

26. Schuster, G. S.: Oral microbiology and infectious disease. $3^{\text {rd }} \mathrm{ed}$. Philadelphia, Decker, 1990.

27. Smyth, A. G., Knepil, G. J.: Prophylactic antibiotics and surgery for primary clefts. Br. J. Oral. Maxillofac. Surg., roč. 46, 2008, č. 2, s. 107-109.

28. Švestková, S.: Přínos mokré terapie v léčbě ran. Medical tribune, roč. 8, 2012, č. 4, s. 2.

29. Thomas, G. P., Sibley, J., Goodacre, T. E., Cadier, M. M.: The value of microbiological screening in cleft lip and palate surgery. Cleft Palate Craniofac. J., roč. 49, 2012, č. 6, s. 708-713.

30.Thurzo, A.: Aktivátory v ortodoncii - vývoj, uplatnenie, modifikácie a mechanizmy účinku. Stomatológ, roč. 18, 2008, č. 2 , s. 3-12.

31. Tuna, E. B.,Topçuoglu, N., Ilhan, B., Gençay, K., Kulekçi, G.: Staphylococcus aureus transmission through oronasal fistula in children with cleft lip and palate. Cleft Palate Craniofac. J., roč. 45,2008 , č. 5, s. 477-480.

32. Urbanová, W., Vaňková, Z., Kotová, M.: Incidence of the orofacial clefts in the Czech Republic in years 1994-2008. Bratislava Med. J., 2013 (v tisku)

33. Urbanová, W., Kotóvá, M. Ortodontická léčba pacienta s obličejovým rozštěpem (1. část) Čes. Stomat., roč. 110, 2010, č. 1, s. 9-13.

34. Van der Velden, U., Winkelhoff, A. J., Abbas, F., De Graff, J.: The habitat of periodontopathic microorganisms. J. Clin. Periodontol., roč. 13, 1986, č. 3, s. 243-248.

MUDr. Wanda Urbanová, Ph.D. Stomatologická klinika 3. LF UK a FNKV Šrobárova 50 10034 Praha 10 e-mail: wanda.urbanova@gmail.com 